\title{
TYÖELÄMÄN MUUTOS HAASTAA TYÖYHTEISÖVIESTINNÄN AJATUSMALLIT
}

\begin{abstract}
Työelämän muutoksen seurauksena työyhteisöjen viestintä on uuden haasteen edessä. Ensinnäkin työybteisöt ovat yhä enemmän tietoon ja tiedon luomiseen perustuvia asiantuntijaorganisaatioita, kun taas työyhteisöviestinnän ajattelumallit ovat pä̈̈osin peräisin industrialismin kulta-ajalta. Toiseksi globalisaation vaikutukset ulottuvat kaikenlaisiin organisaatioibin, ja ulkoinen maailma tunkeutuu työyhteisöjen sisään. Työybteisöjen sisäinen ja ulkoinen elämä ybdentyvät, ja jatkuvat muutokset ja epävarmuus ovat arkipäivää. Työelämä on muuttunut ja muuttuu, mutta ovatko sen perusyksikön eli työybteisön viestinnän käytännöt muuttuneet? Tässä artikkelissa kysyn, millaisia työyhteisöviestinnän paradigmoja voidaan tunnistaa tähänastisen organisaatiotutkimuksen ja viestinnän tutkimuksen perusteella ja löytyykö niille vastaavuutta tämän päivän työelämästä. Johtopäätöksenä esitän, mihin työyhteisöviestinnän tutkimuksen tulisi suuntautua jatkossa.
\end{abstract}

Siirtyminen modernista industrialismin aikakaudesta tieto- ja verkostoyhteiskuntaan on korostanut organisaation ja siten työyhteisön kulttuurista olemusta (Berger \& Luckman 1966). Työyhteisö on viestinnällinen käsite, sillä työyhteisöt syntyvät, toimivat ja hajoavat ihmisten välisen kommunikaation seurauksena. Työyhteisö määritelläänkin usein merkitysjärjestelmäksi, jolla ihmiset tulkitsevat kokemuksiaan ja virittävät aikeitaan. (Esim. Juuti \& Lindström 1995, 19.)

Työelämän tutkimuksessa viestintä on viime aikoihin asti ollut varsin näkymätön ilmiö, vaikka esimerkiksi Suomen olosuhteita peilaava TYKY- eli työkykyparadigma määrittelee työhyvinvoinnin keskeisiksi ulottuvuuksiksi terveyden, työympäristön ja osaamisen lisäksi työyhteisön (Piirainen, Hirvonen \& Elo 2003). Useat viime aikojen työelämän tutkimukset ovat laajentuneet työn fyysisten ominaisuuksien tarkastelusta henkiselle puolelle työkulttuuriin, johtamisjärjestelmiin ja vaikutusmahdollisuuksiin. Henkisen puolen merkitys on noussut esiin muun muassa siksi, että työyhteisöpiirteillä on todettu olevan jopa merkittäviä terveydellisiä vaikutuksia $(\mathrm{mm}$. Rantanen 2004, 21). Työhyvinvoinnin vaikutuksiin ei kuitenkaan tässä artikkelissa puututa. Artikkelissa kysytään, millaisia työyhteisöviestinnän paradigmoja 
on tunnistettavissa tähänastisen organisaatiotutkimuksen ja viestinnän tutkimuksen perusteella ja löytyykö niille vastaavuutta tämän päivän työelämästä. Työyhteisö käsitetään tässä organisaation synonyymiksi.

\section{TYÖN JA TYÖELÄMÄN MUUTOS}

Työelämän meneillään olevaa muutosta verrataan usein 200 vuotta sitten käynnistyneeseen teolliseen vallankumoukseen. Teollinen yhteiskunta on muuttunut tietoyhteiskunnaksi, ja Suomessa kehitys on ollut poikkeuksellisen nopeaa. Suomea ei pidetä ainoastaan yhtenä maailman kehittyneimmistä talouksista vaan myös poikkeuksellisen tasa-arvoisena yhteiskuntana (Castells \& Himanen 2001, 13-20; Pyörï, Melin \& Blom 2005, 45). Toisaalta tilastoissa näkyvät työntekijöiden uupuminen ja pahoinvointi, joka viimeisimpien tutkimusten mukaan olisi kääntynyt parempaan suuntaan ( $\mathrm{mm}$. Työ ja terveys -haastattelututkimus 2006; Torvi \& Kiljunen 2005). Tyytymättömyyttä ovat indikoineet esimerkiksi epävarmuuden kokemukset ja vähäiset vaikutusmahdollisuudet työyhteisöissä.

Työelämän rakennemuutos on sopeutumista maailmantalouden uusiin sääntöihin ja kilpailukyvyn etsimistä eri keinoin. Tukiainen mainitsee uuden talouden työyhteisöjen ominaispiirteinä muun muassa hajautetun toiminnan, verkostoitumisen, matalan hierarkian, tiimi- ja projektityön. Tällainen organisaatio antaa työntekijöille vastuuta ja päätösvaltaa, painottaa asiakassuhteiden tärkeyttä ja tukee toiminnassaan luovuutta ja innovatiivisuutta. (Tukiainen 2006, 14-21.)

Tietotyöammattien osuus kasvaa jatkuvasti. Työvoima 2020 -työryhmän mukaan johto- ja asiantuntijatyön osuus kasvaa eniten perinteisen toimistotyön vähentyessä (Tiainen 2003). Henkisen työvoiman eli tietotyöläisten tai tietämystyöntekijöiden (knowledge workers) määrä on yli kolminkertaistunut kahdentoista vuoden aikana. Vuonna 1988 osuus oli $12 \%$ ja nykyisin yli $40 \%$. (Huotari, Hurme \& Valkonen 2005, 25.) Pyöriä ym. $(2005,14)$ määrittelevät tietotyöläisen seuraavin kriteerein: a) hän käyttää työssään informaatioteknologiaa, b) työ on keskeisiltä osiltaan riippumatonta suunnittelua ja ideointia, c) hänellä on vähintään toisen asteen ammatillinen koulutus.

2000-luvun tietotyöläinen käyttää tietoa intellektuaalisuutta ja asiantuntemusta vaativalla tavalla sekä toimii itseohjautuvasti. Castells (2000) puhuu symbolianalyyttisesta työstä, joka edellyttää monenlaista ongelman tunnistamis- ja ratkaisukykyä. Tällaista on esimerkiksi strateginen päätöksenteko ja suunnittelu, innovaatioiden tuottaminen ja soveltaminen sekä näihin liittyvä päätöksenteko ja johtaminen. Hannele Huhtala (2004, 285-295) kehitti väitöskirjassaan käsitteen emansipoitunut työntekijä, jossa korostuu yksilön subjektius ja irtautuminen perinteiseen palkkatyöhön liitetystä ulkoisesta kontrollista, byrokratiasta ja hierarkkisista organisaatiorakenteista.

\section{TYÖYHTEISÖSUHDE MUUTTUU}

Tietotyöläisen suhde organisaatioon ja hänen odotuksensa sitä kohtaan voivat olla ristiriitaisia. Hän voi olla emotionaalisesti sitoutunut työhön ja organi- 
saatioon sekä suhtautua myönteisesti tiedon ja osaamisen jakamiseen. Hänen suhteensa organisaatioon voi kuitenkin olla myös löyhä tai välinpitämätön, jolloin omaa osaamista tai ideoita ei jaeta pyyteettömästi. (Juholin 2007.) Niin sanotun postmodernin työntekijän ominaisuuksia on kuvattu siten, että postmoderni työntekijä haluaa osallistua organisaation kehittämiseen ja vaikuttaa yhteisiin asioihin vähemmän kuin aiemmin on ajateltu. Työntekijä voi myös suhtautua organisaatioon laskelmoivasti (Joensuu 2006, 165, 185).

Byrne (2001) nostaa esiin työelämän uuden sopimuksen, jossa oleellista ei ole enää keskinäinen lojaalisuus, luottamus ja sitoutuminen. Sen sijaan työntekijät toimivat oman etunsa mukaan eräänlaisina sisäisinä yrittäjinä. He ottavat riskejä, huolehtivat omasta työmarkkinakunnostaan eivätkä odota työnantajan ottavan siitä vastuuta.

Työelämän vanha sopimus on analoginen psykologisen sopimuksen kanssa. Jälkimmäinen tarkoittaa uskomusta siitä, että työelämän osapuolilla on yhtäältä oikeus saada hyötyä antamastaan panoksesta. Toisaalta he sitoutuvat toisiinsa ja työyhteisöönsä (Morrison \& Robinson 1997) ja uskovat, että oman työpaikan taloudellisella menestymisellä sekä oman aseman ja työsuhteen avulla saatavien erilaisten palkkioiden välillä on kiinteä yhteys. Psykologisen sopimuksen historiallisena esikuvana mainitaan usein patruunoiden aikakausi teollistumisen alkuvaiheessa. Suomessa on toteutettu 1990-luvulta lähtien työministeriön tilaamaa ja Tilastokeskuksen toteuttamaa työolobarometria, jonka pohjalta Tuomo Alasoini (2006) on tehnyt Työelämän kehittämisohjelman (Tykes) toimeksiannosta analyysin Työnteon mielekkyyden muutos Suomessa vuosina 1992-2005. Sen johtopäätöksenä todettiin, että suomalaisten palkansaajien psykologinen sopimus säröilee.

Elinkeinoelämän valtuuskunnan EVAn tutkimuksen (Torvi \& Kiljunen 2005) mukaan työntekijöiden ja työnantajien etua yhteneväisinä pitävien osuus oli Suomessa vuonna 2004 selvästi alempi kuin kertaakaan viimeisten kymmenen vuoden aikana. Toisaalta taas loppuun palamisen kokeneiden määrä oli vähentynyt vuosina 1996-2004. Siltala (2004, 10-16) puolestaan antoi suomalaisesta työelämästä lähes lohduttoman kuvan. Hänen mukaansa globaali hyperkilpailu on heikentänyt useimpien työntekijöiden työn vaihtoarvoa ja stressistä, uupumuksesta ja depressiosta on tullut laajasti levinnyt kansantauti. Toisaalta brittiläinen taloustieteen professori Francis Green (2006, ref. Alasoini 2006) pitää Suomea poikkeuksena työn laadun huononemisen yleisestä trendistä.

Viimeaikaiset tutkimukset, kuten työministeriön vuoden 2004 työolobarometri, Tilastokeskuksen työolotutkimus ja Työterveyslaitoksen Työ ja terveys Suomessa 2003 eivät viittaa siihen, että näkemykset työnteon ehdoista olisivat muuttuneet viime vuosina pessimistisemmiksi. Kyse on enemmän uhkaaviksi koettujen toimintamallien yleistymisestä kuin oman työpaikan ja arjen muutoksista. (Antila \& Ylöstalo 2002; Alasoini 2006.) Työterveyslaitoksen tekemän haastattelututkimuksen mukaan $(\mathrm{n}=3122)$ työssäkäyvistä ihmisistä 40 prosenttia koki innostusta työtään kohtaan. Stressioireet ovat vähentyneet tasaisesti työssäkäyvillä vuodesta 1997 lähtien. Työn henkinen rasittavuus on pysynyt samalla tasolla; 34 prosenttia kokee työnsä henkisesti hyvin tai melko rasittavaksi. (Työ- ja terveys -haastattelututkimus 2006.) 


\section{TYÖELÄMÄN UUSI PARADIGMA}

Jännite työelämän vanhan ja uuden sopimuksen välillä näyttää ilmeiseltä. Konfrontaatio syntyy autoritaarisuuden ja itseohjautuvuuden, objektiuden ja subjektiuden rajapinnoilla. Työnteon paradigman muutosta pohtinut Sirkka Heinonen $(2004,66-67)$ ottaa yhtenä ilmentymänä esiin uudet organisaatiorakenteet. Ne ovat aiempia mukautumiskykyisempiä, sillä ne muodostuvat ydintyöntekijöistä, täydentävistä työntekijöistä ja ulkoistetuista työtoiminnoista. Työntekijät viettävät yhä enemmän ajastaan väliaikaisissa, projektipohjaisissa ryhmissä. Joustavuutta haetaan sekä toiminnallisesti että määrällisesti, joista edellinen viittaa työtehtävien laajentumiseen ja jälkimmäinen työaikaan, ulkoistamiseen ja muihin järjestelyihin (Kasvio 1995, 46-47).

Uuden paradigman on todettu tuottavan epävarmuutta ja turvattomuutta. Bordia ym. (2004) luokittelevat muutokseen liittyvän epävarmuuden kolmeen toisiinsa liittyvään tyyppiin: strategiseen, rakenteelliseen ja työhön liittyvään. Työhön liittyvän epävarmuuden kokeminen on voimakkaampaa kuin strateginen tai rakenteellinen epävarmuus. Kirjoittajien mukaan viestinnän ja tiedon lisääminen ei ole ratkaisu silloin, kun ihmiset tuntevat epävarmuutta ja kokevat olevansa kaaoksen keskellä. Osallistavan päätöksenteon mallissa (PDM= model of participation in decision-making) oleellista on vähentää epävarmuuden tunteita lisäämällä kasvokkaisviestintää ja erilaisia ryhmä- ja yhteistyön menetelmiä.

Ståhle ja Grönroos (1999, 82-107) lähestyvät asiaa toimintaympäristön muutoksen kautta. He jäsentävät toimintaympäristön kolmeen ulottuvuuteen, mekaaniseen, orgaaniseen ja dynaamiseen. Ensin mainitulle on ominaista lineaarinen tiedon virtaus ylhäältä alas. Mekaanisessa toimintaympäristössä tärkeää on tiedon kulku ja tiedon saatavuus, sillä systeemiä hallitaan yhtenäisen tiedon avulla. Orgaanisessa toimintaympäristössä korostuvat dialogi ja palautejärjestelmät sekä yhteisen tulkinnan kautta synnytetyt merkitykset. Dynaamisessa ympäristössä kohdataan tietämättömyyttä, ennakoimattomuutta ja kaaosta, mikä on usein edellytys uuden luomiselle. Dynaaminen ympäristö vaatii kirjoittajien mukaan paljon spontaanisuutta, avoimuutta ja vapaata informaation vaihdantaa.

Akseli Virtanen tavoittaa ilmiötä väitöskirjassaan Biopoliittisen talouden kritiikki (2006). Teos tarkastelee henkisen työvoiman syntyä yhteiskuntamme uutena tilattomana ja rajattomana subjektina. Virtanen tutkii henkisen työvoiman aiheuttamaa muutosta yritysten ja koko yhteiskunnan organisoitumisen tavoissa. Virtasen keskeisiä teesejä on, että kommunikaatio ja sosiaalinen vuorovaikutus on saanut tuotannossa ja taloudellisen arvon luomisessa yhä tärkeämmän roolin. Henkinen työvoima elää ja vahvistuu siellä, missä on dialogia, mutta se ei välttämättä kiinnity organisaatiorakenteisiin.

Jatkuvan muutoksen välttämättömyyden ymmärtäminen on tuonut työelämän tutkimukseen uuden näkökulman. Työelämää ja työyhteisöjä ei käsitellä vain järjestykseen ja tasapainoon tähtäävinä entiteetteinä vaan hajottavina ja pirstaleisina, mitä kuvaa hyvin dissipaation käsite. Venkulan (2005, 41-42) mukaan dissipaatio on monien tekijöiden äkillinen epäjatkuvuus, ja tämä epätasapaino aiheuttaa jatkuvaa epävakautta ja liikettä. Aula $(1999,129)$ kuvaa dissipatiivista muutosta symmetrian murtumiseksi, järjestelmän rakenteelliseksi epävakaudeksi ja kontrollin kadoksi. 
Muutosten keskellä esimiehen rooli on yhä keskeinen, samoin vaikuttaminen omaan työhön ja työyhteisöön koetaan tärkeäksi (mm. Simola \& Kinnunen 2005, 119-139). Keskinen (2005, 18-21) korostaa alaisen vastuuta työyhteisönsä kehittämisessä. Antila ja Ylöstalo (2004) kirjoittavat proaktiivisista työpaikoista, joissa päätöksentekoa on delegoitu alhaalta ylöspäin. Tämä vähentää työntekijöiden lähtökohtaisesti negatiivisia tulkintoja työnantajan ratkaisuja kohtaan. Antila (2006) kirjoittaa, että myönteinen palaute, yleinen avoimuus ja ihmisten huomioonottaminen sekä työpaikan henki ovat edelleen asioita, jotka vaikuttavat kokemukseen työn mielekkyydestä. Myös Goris, Vaught \& Petitt (2000) osoittivat, että työsuoritus ja työtyytyväisyys kasvavat, kun työntekijän yksilölliset tarpeet ovat tasapainossa työn ominaisuuksien kanssa. Tämä merkitsee, että työ koetaan mielekkääksi ja olosuhteet vakaiksi.

Edellisen pohjalta työyhteisölle on muodostettavissa kolme paradigmaehdotusta, jotka voivat seurata toisiaan historiallisena jatkumona tai elää rinnakkain. Traditionaaliset työyhteisöt, heijastavat industrialismin ihanteita ja pyrkivät hallittavuuteen. Proaktiiviset työyhteisöt ovat omaksuneet yhteisöllistävän tavan toimia, ja niille on tunnusomaista päätöksenteon delegointi organisaatiossa alas. Uuden työn ja työyhteisön paradigma korostaa epäjatkuvuutta, epävarmuutta ja yksilön vastuuta oman elämänsä ja uransa haltuun ottamisessa. Sitä kutsutaan tässä turbulentiksi työyhteisöksi.

Paradigman käsitteen olemassaolon oikeutusta voi kyseenalaistaa nykymaailmassa. Jos toimintaympäristö on dynaaminen, voivatko ajatusmallitkaan saavuttaa koskaan staattista tilaa, mitä paradigma pohjimmiltaan ilmentää? Thomas Kuhn (1962) totesi runsaat 40 vuotta sitten , että tiede ei niinkään esiinny yksittäisten teorioiden kehityksenä vaan paradigman vaihdoksina. Sellainen on perusteellinen ja selvä muutos tavassa hankkia tietoa ja tulkita sitä. Uusi paradigma muuttaa tiedettä, sitten teknologiaa ja lopulta ihmisten elämää ja yleistä näkemystä tarkastelun kohteena olevasta ilmiöstä.

\section{VIESTINTÄAJATTELUN KEHITYSKAARELLA}

Tämä artikkeli myötäilee Kuhnin ajattelua ja olettaa, että yksittäistä teoriaa laajempia ajatusmalleja on tunnistettavissa, mutta välttämättä ne eivät seuraa toisiaan järjestelmällisesti. Seuraavaksi kysyn, millaisia työyhteisöviestinnän paradigmoja voidaan muotoilla tähänastisen tutkimuksen pohjalta. Apuna käytetään tunnettujen tutkijoiden metaforia (Morgan 1997; Hatch 1997).

Organisaatio koneena oli Fredrick Taylorin (1911) luoman klassisen teorian ydinajatus. Sen mukaan organisaatio on rationaalinen ja tekninen prosessi ilman inhimillisiä ominaisuuksia. Max Weber (1924/1947) toi tietoisuuteen ihanteellisen byrokraattisen organisaation, jolle on ominaista säännöt ja säätely, organisaation jäsenten eriytyneet roolit ja tarkat työnkuvat, hierarkkisuus, järjestelmällisyys ja ennustettavuus. Samaa ajattelua jatkoi 1930-luvulla syntynyt ihmissuhdeteoria (Human Relations Theory), joka nosti esiin yksilön ja yksilöiden suhteiden merkityksen.

Viestintä sanomien siirtoprosessina on yllättävän samankaltainen klassisen teorian kanssa, koska siinä viestintä nähdään suunnitelmallisena ja yksisuuntaisena tapahtumaketjuna. Johto kontrolloi sekä viestinnän suuntaa että sisältöjä. Taustalla on Shannonin ja Weaverin vuonna 1949 kehittämä matemaatti- 
nen teoria (A Mathematical Theory of Communication), jossa viestinnän tarkoitus on luoda järjestystä ja vähentää epäjärjestystä.

Danielsin, Spikerin ja Papan $(1997,8-9)$ mukaan tämä traditionaalinen, viestinnän tehokkuutta ja mitattavuutta korostava ajatusmalli oli vahvimmillaan 1960- ja 70-luvuilla. Miller määrittelee mekanistisen organisaation viestinnän yhteisiksi piiteiksi monoliittisuuden, joka ei kannusta työntekijöiden väliseen viestintään, vertikaalisen viestinnän ylivoimaisuuden, kirjallisten kanavien hallitsevan roolin, virallisen tyylin sekä viestintäpolkujen hierarkkisuuden (Miller 2003, 18-19). Tuoreen suomalaisen tutkimuksen mukaan viestinnän lineaarisuutta ja yksisuuntaisia kanavia korostava ajattelu on edelleen melko vahva, joskin sen merkitys varsinkin tietointensiivissä työyhteisöissä horjuu (Juholin 2007).

Organisaatio eliönä oli 1950-luvulla syntynyt teoria, joka sai vaikutteita luonnontieteistä Ludwig von Bertalanffyn (1968) yleisen systeemiteorian (General Systems Theory) myötä. Sen mukaan organisaatio on kompleksinen järjestelmä, jonka osat ovat jatkuvassa vuorovaikutuksessa ympäristön kanssa ja muokkaavat toimintaansa saavuttaakseen tavoitteensa. Systeemiteoriasta jalostui kontingenssiajattelu, jossa keskeiseksi nousi joustavuus sopeutua ympäristön vaatimuksiin ja hyödyntää ympäristöstä saatavaa tietoa. (Lawrence $\&$ Lorsch 1967.)

Viestinnän kontingenssi- eli sovitemallin mukaan ybtä oikeaa tapaa johtaa viestintää ei ole, vaan kullekin organisaatiolle on löydettävä sille tietyissä olosuhteissa sopiva viestinnän tapa. Sisäisiksi ja ulkoisiksi sovite- eli kontingenssitekijöiksi määriteltiin muun muassa organisaation rakenne, organisaation jäsenten demografiset ominaisuudet, tuotteet ja tuotanto, maantieteellinen sijainti ja historiaa, johtajien kyvykkyys, yksilö- ja ryhmäominaisuudet sekä inhimilliset, taloudelliset ja tekniset resurssit. (Goldhaber, Dennis \& Wiio 1979; Wiio 1978/1995; Åberg 1989.)

Vaikka klassinen teoria, ihmissuhdeteoria ja systeemiteoria kontingenssiajattelulla täydennettynä vaikuttavat aluksi varsin erilaisilta, niiden ydin on lopulta hyvin samankaltainen. Yhteistä on uskomus, että tulevaisuutta voidaan ennakoida ja että olosuhteita on mahdollista hallita. Tämän uskomuksen kanssa analoginen viestintänäkemys korostaa sanomien siirtoa ja hallittua viestintäketjua, vaikka varsinkin kontingenssiajattelu tarjoaa laajempaa ja joustavampaa näkemystä ja ympäristön huomioon ottamista.

Organisaatio kulttuurina perustuu kulttuurimetaforalle ja saa lähtöoletuksensa antropologiasta ja sosiologiasta. Siinä yhdistyvät tavat ja traditiot, tarinat, myytit, artefaktit ja symbolit, kieli, normit ja seremoniat (Hatch 1997; Morgan 1997). Organisaatio on siis jaettujen uskomusten ilmentymä. Organisaation suhdetta ympäristöönsä ei nähdä ainoastaan toimintojen sarjana ja jatkumona vaan sosiaalisesti rakentuneena ja jatkuvassa liikkeessä olevana.

Viestinnän merkityskoulukunta on analoginen edellisen kanssa (Fiske 1982). Siinä ei olla niinkään kiinnostuneita sanomien siirrosta vaan ennen kaikkea siitä, miten merkitykset syntyvät vastaanottajien mielissä. Viestinnän merkitys-eli semioottinen koulukunta on tuottanut laajasti levinneen johtamisopin merkitysten johtamisesta, jossa johtajan ja esimiehen keskeisenä tehtävänä on tuottaa viestinnällä sisältö organisaation keskusteluun.

Organisaatio jatkuvana liikkeenä saa ideansa luonnontieteistä, erityisesti kaaosteoriasta. Morganin (1997, 251-254) kuvaaman muutoksen käänteisen 
logiikan mukaan organisaatio elää jatkuvassa liikkeessä ikään kuin joen pyörteissä. Dissipatiivinen ajattelu haastaa viestinnän aiemmat koulukunnat ja väittää, että toimintaympäristöt ja organisaatiot ovat kaukana ennustettavuudesta ja johdettavuudesta.

Aula (1999) hyödyntää tätä ajattelua muodostaessaan organisaatioviestinnän dynaamisen mallin. Hän määrittelee viestinnälle kaksoisfunktion: integroiva viestintä ohjaa organisaatiota järjestykseen, kun taas dissipatiivinen vähentää sitä ja voi johtaa kohti lisääntyvää epäjärjestystä. Dissipatiivinen viestintä on 2000-luvun taitteen käsite, joka hämmentää etenkin viestinnän prosessimalliin vihkiytyneitä. Se on kuitenkin ansiokkaasti tuulettanut luutuneita käsityksiä ja antanut samalla aineksia pohtia, voiko ei-johdettu ja spontaani viestintä tuoda jotain uutta työyhteisöjen arkeen. Keskeiseen asemaan nousee luottamus. Huotari ym. $(2005,106)$ korostavat, että luottamus vaikuttaa siihen, miten tietoa jaetaan työyhteisössä: "Tiedon jakaminen on sitä, että yhteisön jäsen ei piilota eikä salaa toisiltaan osaamista ja asiantuntemustaan vaan käyttää sitä ja viestii siitä."

Organisaatiot kollaasimaisina ybteisöinä on vastakohta tai vaihtoehto turbulenssille. Hatchin (1997, 54-55) typologioissa kollaasi edustaa postmodernia. Siinä kollaasi nähdään mosaiikkimaisena teoksena, jossa osaset on järjestelty uudella, ennalta arvaamattomalla tavalla. Organisaatio siis järjestäytyy jatkuvasti uudelleen ja synnyttää uusia yhteisöjä ja uutta ajattelua. Tulevaisuuden tutkija Heinonen $(2004,82)$ on samoilla linjoilla todetessaan, että tulevaisuudessa työpaikka on enemmän prosessi kuin paikka, ja että ihmisten on opittava toimimaan jatkuvasti muuttuvassa ympäristössä. Jatkuvassa liikkeessä elävä organisaatio etsii eheyttä ja ymmärrystä yksilöiden välisen vuorovaikutuksen avulla, mikä parhaimmillaan voi vahvistaa yhteisöllisyyttä ja keskinäistä vastuullisuutta. Kun loppumaton liike nähdään dissipatiivisessa ajattelussa enemmänkin uhkana, kollaasiajattelu näkee siinä mahdollisuuksia uuden luomiseen.

Sama ybteisöllisyyden ja vastuullisuuden ajattelu näkyy myös taloustieteistä alkunsa saaneessa yhteiskuntavastuu- ja sidosryhmäajattelussa. (Stanford Research Institute 1963, ref. Freeman 1984; Rhenman 1964; Freeman 1984; 1995; Carroll 1989; 1991; Näsi 1995). Yritysten yhteiskuntavastuun uudelleen syntymistä on vauhdittanut ympäristövastuun tunnistaminen, jota täydensivät 1990luvun lopulla sosiaalinen ja taloudellinen vastuu (corporate social responsibility). Yhteiskuntavastuu-ajattelua käynnisti John Elkingtonin (1997) artikuloima kolmoistilinpäätös (triple bottom line), joka sisältää taloudellisen, sosiaalisen ja ympäristövastuun. Tätä on myöhemmin täydennetty kulttuurisella vastuulla (Juholin 2004, 14). Adler ja Heckscher (2006, 15-17) kuvaavat tätä ajattelua uudenlaisella yhteisöllisyyden mallilla (new form of community), jonka keskeisiä ominaisuuksia ovat muun muassa yhteisön jäsenten keskinäinen luottamus, yhteinen tiedon generointi ja jakaminen. Muita ominaisuuksia ovat työyhteisön jäsenten keskinäinen riippuvuus, samanaikainen yksilöllisyys ja kollegiaalisuus sekä toisistaan välittäminen ja toistensa auttaminen.

Vastuullinen viestintä on stakeholder-ajattelun ja erityisesti stakeholder-dialogin viestinnällinen vastine. Stakeholder-ajattelun lähtökohta on, että organisaatioilla on erilaisia stakeholder-ryhmiä ja -henkilöitä, joista organisaatio on riippuvainen, ja jotka vastaavasti ovat riippuvaisia organisaatiosta tai kiinnostuneita vaikuttamaan sen asioihin. Nämä ryhmät ja henkilöt muodostavat keskenään verkostoja ja synnyttävä vaikuttamisen potentiaalia. Organisaatio ansait- 
see, vahvistaa tai heikentää legitimiteettiään stakeholdereidensa arvioissa. Stakeholder-dialogi alleviivaa tasavertaista ja arvostavaa keskustelua organisaation stakeholdereiden kesken. Suhde ei tarkoita vain taloudellista vaihdantaa vaan keskinäisen riippuvuuden ymmärtämistä. Stakeholder-dialogi sisältää implisiittisesti vastuullisuuden, koska dialogi on asettumista tasavertaiseen keskusteluyhteyteen, toisen avointa kuuntelua ja pyrkimystä molemminpuoliseen ymmärrykseen. (Mm. April 1999.) "Stakeholderismia" on myös kritisoitu liiasta idealismista sillä, lopulta yleensä omistajien intressi ratkaisee. Myös stakeholdereiden määrittely on laajentunut perinteisestä henkilöstöstä, asiakkaista ja omistajista jopa anonyymeihin kuluttajiin, jolloin organisaatioiden on vaikea päästä heidän kanssaan aitoon dialogiin. (Barry 2002.)

Keskinäisen vastuullisuuden näkemys edustaa välimuotoa kahden edellisen ajattelutavan eli hallintaan tähtäävän viestinnän ja hallitsemattoman kaaoksen välillä. Kun klassinen koulukunta näkee organisaation koneena ja moderni koulukunta osana luontoa, postmoderni vastuullisuutta korostava koulukunta kohdistaa huomionsa ihmisiin. Ellei oteta huomioon antiikin filosofien dialogikäsityksiä, dialogisuus työntyi eksplisiittisesti organisaatioviestintään (PR) Grunigin ja Huntin (1984) mallissa, jota Grunig ja Grunig (1992) myöhemmin täydensivät. Heille kahdensuuntainen asymmetrinen viestintä on luonteeltaan suostuttelevaa, vaikka siihen sisältyykin palautteen kerääminen. Kahdensuuntainen symmetrinen kommunikaatio on luonteeltaan yhteistoimintaa, joka pyrkii molemminpuolisen ymmärtämyksen saavuttamiseen.

Viestinnän rooli on siis liikkunut kontrolloidusta sanomien siirrosta dissipaatioon ja takaisin keskinäiseen dialogiin ja vastuullisuuteen. Taulukko 1 esittää, miten organisaatiometaforien pohjalta voidaan kuvata myös viestintää.

\section{Taulukko 1. Organisaatiometaforat täydennettyinä organisaation, johtajan ja} viestinnän "kuvilla" (Hatchia [1997] ja Morgania [1997] soveltaen)

\begin{tabular}{|c|c|c|c|}
\hline $\begin{array}{l}\text { Organisaatio- } \\
\text { metafora } \\
\text { [Perspektiivi] }\end{array}$ & $\begin{array}{l}\text { Organisaatio } \\
\text { nähdään ... }\end{array}$ & Johtaja nähdään ... & Viestintä nähdään ... \\
\hline $\begin{array}{l}\text { Kone } \\
\text { [Klassinen] }\end{array}$ & $\begin{array}{l}\text { koneena, joka on suunniteltu } \\
\text { saavuttamaan organisaation } \\
\text { tavoitteet }\end{array}$ & $\begin{array}{l}\text { insinöörinä, joka } \\
\text { suunnittelee ja } \\
\text { johtaa operaatioita } \\
\text { organisaatiokoneella }\end{array}$ & $\begin{array}{l}\text { kontrolloituna järjestelmänä, } \\
\text { jonka kanavia ja käytäntöjä } \\
\text { johto hallinnoi }\end{array}$ \\
\hline $\begin{array}{l}\text { Eliö } \\
\text { Moderni] }\end{array}$ & $\begin{array}{l}\text { eliönä, joka suorittaa } \\
\text { organisaation selviytymisessä } \\
\text { välttämättömiä toimia }\end{array}$ & $\begin{array}{l}\text { ympäristöön sopeutuvan } \\
\text { järjestelmän eri tekijöistä } \\
\text { riippuvana osana }\end{array}$ & $\begin{array}{l}\text { ympäristöä tunnistavana ja sen } \\
\text { kanssa yhteistyötä tekevänä } \\
\text { järjestelmänä }\end{array}$ \\
\hline $\begin{array}{l}\text { Kulttuuri } \\
\text { [Symbolis- } \\
\text { tulkinnallinen] }\end{array}$ & $\begin{array}{l}\text { merkityskokonaisuuksina, } \\
\text { jotka syntyvät ja joita } \\
\text { ylläpidetään ihmisten } \\
\text { vuorovaikutuksella ja joissa } \\
\text { ovat mukana jaetut arvot, } \\
\text { traditiot ja tavat }\end{array}$ & $\begin{array}{l}\text { artefaktina, joka symboloi } \\
\text { koko organisaatiota }\end{array}$ & $\begin{array}{l}\text { yhteisöllisyyden ja yhteisten } \\
\text { merkitysten luomisena ja } \\
\text { ylläpitämisenä }\end{array}$ \\
\hline $\begin{array}{l}\text { Kollaasi } \\
\text { [Postmoderni] }\end{array}$ & $\begin{array}{l}\text { koosteena, joka syntyy } \\
\text { uudesta ja vanhasta } \\
\text { tiedosta ja ymmärryksestä } \\
\text { muodostaen siitä jatkuvasti } \\
\text { uudistuvia yhdistelmiä }\end{array}$ & $\begin{array}{l}\text { samaan aikaan } \\
\text { teoreetikkona, taiteilijana } \\
\text { ja tiedon yhdistäjänä }\end{array}$ & $\begin{array}{l}\text { vuorovaikutuksena, jossa } \\
\text { kunnioitetaan yksilöitä, } \\
\text { hyödynnetään erilaisuutta, } \\
\text { verkostoidutaan ja muodostetaan } \\
\text { uusia yhteisöjä }\end{array}$ \\
\hline $\begin{array}{l}\text { Kompleksisuus, liike, } \\
\text { jatkuva muutos } \\
\text { [Postmoderni] }\end{array}$ & $\begin{array}{l}\text { perhosefektin tapaisena } \\
\text { ilmiönä, jossa pieni liike } \\
\text { yhtäällä aiheuttaa suuren } \\
\text { muutoksen toisaalla }\end{array}$ & $\begin{array}{l}\text { paradoksien hallintana } \\
\text { ja itsekin osana jatkuvaa } \\
\text { muutosta }\end{array}$ & $\begin{array}{l}\text { luopumisena hallinnan ideaalista } \\
\text { ja sen tunnustamista, että kaikki } \\
\text { ei ole suunniteltavissa }\end{array}$ \\
\hline
\end{tabular}


Taulukon pohjalta voidaan muodostaa seuraavanlaisia metaforapareja kuvaamaan organisaation ja viestinnän keskinäistä riippuvuutta:

- Organisaatio koneena - viestintä koneen "rattaana"

- Organisaatio eliönä - viestintä ympäristöön reagoivana eliön "raajana"

- Organisaatio kulttuurina - viestintä merkityksiä luovana "aarrearkkuna"

- Organisaatio kollaasina - viestintä toisiinsa kiinnittyvinä ja muuttuvina verkostoina ja uusina yhteisöinä

- Organisaatio jatkuvana muutoksena - viestintä myllerryksenä ja katkoksina.

\section{TYÖYHTEISÖVIESTINNÄN PARADIGMAT}

Jotta voitaisiin puhua yhteisöviestinnän paradigmoista, metaforista tulisi tunnistaa syvätason piilevät perusoletukset ja tiivistää ajattelua seuraavaan tapaan.

1) Organisaatio koneena ja viestintä koneen rattaana edustaa samaa ajattelua kuin organisaatio eliönä ja viestintä yhtenä eliön ulottuvuutena. Yhteistä on systeemikeskeisyys, viestintä on alistettu järjestelmän palvelemiseen. Tausta-ajatus on rationaalisuus.

2) Organisaatio kaaoksena ja viestintä katkoksina -ajattelulle on ominaista olosuhteiden ennakoimattomuus ja mahdottomuus ottaa haltuun tilanteita. Tausta-ajatuksena on dissipaatio eli hajaannus ja epäjatkuvuus.

3) Organisaatio kulttuurina ja viestintä merkitysten aarrearkkuna muistuttaa ajattelua organisaatiosta kollaasina ja viestinnästä yksilöiden ja verkostojen välisenä yhteisöllisyytenä. Yhteistä ovat yksilöt ja heidän välinen yhteisöllisyytensä ja merkityksenantonsa. Tausta-ajatuksena on dialogi ja keskinäinen vastuullisuus.

Yllä esitetyt ajatuskonstruktiot edustavat kolmea perusluonteista oletusta työyhteisöviestinnästä ja redusoivat ne ylemmän tason käsitteiksi. Ne edustavat työyhteisöviestinnän paradigmoja, jotka tässä nimetään rationaaliseksi, dissipatiiviseksi ja dialogiseksi.

Seuraavaksi vertailen työyhteisön ja työyhteisöviestinnän paradigmoja keskenään ja etsin vastausta tutkimuskysymykseen, onko niillä jotain yhteistä.

\section{PARADIGMA KOHTAA PARADIGMAN}

Työyhteisön paradigmoina esitettiin edellä traditionaalinen, proaktiivinen ja turbulentti. Työyhteisöviestinnän paradigmoiksi muotoiltiin rationaalinen, dialoginen ja dissipatiivinen. Perusoletustensa mukaan ne voidaan asettaa rinnakkain siten, että työyhteisön traditionaalinen paradigma asettuu rationaalisen viestintäparadigman ja proaktiivinen työyhteisöparadigma viestinnän dialogisen paradigman pariksi. Dissipatiivinen viestintäparadigma putoaa näiden väliin, ja sille löytyy vastinpari parhaiten turbulentista työyhteisöparadigmasta. Näistä voidaan muodostaa teoreettisia yhdistelmiä seuraavasti. 
Taulukko 2. Työybteisön ja työybteisöviestinnän paradigmojen vertailua

\begin{tabular}{|l|l|l|l|}
\hline \multicolumn{1}{|c|}{$\begin{array}{c}\text { Viestintä } \\
\text { Työ- } \\
\text { yhteisö }\end{array}$} & Rationaalinen & Dissipatiivinen & Dialoginen \\
\hline Traditionaalinen & & $\begin{array}{l}\text { Hierarkkinen organisaatio } \\
\text { Sporadis-spontaani viestintä }\end{array}$ & $\begin{array}{l}\text { Hierarkkinen organisaatio } \\
\text { Yhteisöllisyyttä vahvistava viestintä }\end{array}$ \\
\hline Turbulentti & $\begin{array}{l}\text { Turbulentti organisaatio } \\
\text { Monologinen viestintä }\end{array}$ & $\begin{array}{l}\text { Turbulentti organisaatio } \\
\text { Yhteisöllisyyttä vahvistava viestintä }\end{array}$ \\
\hline Proaktiivinen & $\begin{array}{l}\text { Osallistava työyhteisö } \\
\text { Monologinen viestintä }\end{array}$ & $\begin{array}{l}\text { Osallistava työyhteisö } \\
\text { Sporadis-spontaani viestintä }\end{array}$ & \\
\hline
\end{tabular}

Tummennetuissa ruuduissa oletetaan, että työyhteisön ja viestinnän paradigmat ovat toistensa vastinparit ja ilmenevät yhdessä. Eräänlaisena ideaalina voidaan tämänhetkisen tutkimuksen pohjalta pitää työyhteisöä, joka toimii proaktiivisesti ja jossa viestintä on dialogista, yhteisöllisyyttä vahvistavaa. Samalla logiikalla voisi väittää, että muita mahdollisia yhdistelmiä ovat hierarkkiset organisaatiot, joissa harjoitetaan monologista viestintää tai turbulentit organisaatiot, joiden viestintä on sporadis-spontaania. Sillä tarkoitetaan katkonaista ja satunnaista viestintää, jota kukaan ei johda, eivätkä myöskään organisaation jäsenet tunnista omia vastuitaan.

Normatiivisesti voitaisiin väittää, että mikäli työyhteisö pyrkii olemaan proaktiivinen, sen viestintää tulisi kehittää kohti dialogiparadigmaa. Mielenkiintoista olisi selvittää, voivatko "eripariset" paradigmat toimia käytännössä, esimerkiksi yksiääninen viestintä proaktiivisesti toimivassa työyhteisössä tai sporadis-spontaani viestintä traditionaalisessa työyhteisössä. Tällaisella kysymyksenasettelulla työyhteisöviestintää ei ole tutkittu. Uudeksi kysymykseksi nouseekin, missä määrin työyhteisön paradigma määrittää viestintää tai päinvastoin: millainen riippuvuus niiden välillä vallitsee vai vallitseeko.

\section{TILAA NELJÄNNELLE PARADIGMALLE}

Artikkelin pääkysymys oli, millaisia työyhteisöviestinnän paradigmoja voidaan tunnistaa tähänastisen organisaatio- ja viestintätutkimuksen perusteella ja vastaavatko ne 2000-luvun työelämän piirteitä ja kehitystä. Artikkelissa tunnistettiin kolme työyhteisön ja työyhteisöviestinnän paradigmaa, ja niillä todettiin olevan teoreettiset vastinparit. Työelämän tutkimuksesta siis löytyy vastaavuutta viestintäajatteluun, mikä vahvistaa alussa esitettyä oletusta siitä, että työyhteisö on viestinnällinen käsite.

Toisin kuin Kuhn (1962) väitti, paradigmat eivät välttämättä seuraa toinen toistaan, vaan ne voivat elää samanaikaisesti. Sellainen tilanne on parhaillaan, kun kolme tässä tunnistettua paradigmaa hakevat elintilaansa. Perinteinen rationaalinen paradigma on vahvasti läsnä tämän päivän organisaatioviestinnän tutkimuksessa ja -koulutuksessa. Perusoletuksena on viestinnän näkeminen tiedon hallittuna siirtona, mikä vahvistaa mekanistista organisaatiokäsitystä.

2000-luvun taitteessa nousi esiin samanaikaisesti kaksi hyvin erilaista paradigmaa: luonnontieteisiin tukeutuva dissipatiivinen ja yhteisöllisyyteen 
nojaava dialoginen paradigma. Ensin mainittu saa tukea työelämän ja toimintaympäristön dynaamisuudesta ja turbulenssista, kun taas jälkimmäinen nojaa itseohjautuvuuteen, keskinäiseen vastuullisuuteen ja luottamukseen. Ilmeiseltä kuitenkin näyttää, että tietotyön ja organisaatiorakenteiden madaltumisen myötä 1950-luvulta peräisin olevan rationaalisen paradigman elintila kapenee.

Lopuksi voidaan kysyä, riittävätkö kolme paradigmaa kuvaamaan tämän päivän työyhteisöviestintää. Sanna Joensuu esittää (2006, 185), että uusi näkemys viestinnästä on nousemassa esiin. Siinä viestinnästä tulee väline itsensä kehittämisessä, jolloin viestintä tarjoaa mahdollisuuden löytää organisaatiosta uutta tietoa ja osaamista, joista on hyötyä tulevaisuudessa. Hänen näkemyksensä mukaan tietotyöläinen ei ole kiinnostunut jakamaan tietoaan ja osaamistaan muille vaan häntä kiinnostaa vain se, mistä on hyötyä omalle uralle. Laskelmoivuus voi olla yksilön egoismia ja aiheuttaa jännitteitä, mutta se voi olla myös työyhteisöä raikastavaa ja itsetutkisteluun kannustavaa. Laskelmoivuus ja välinpitämättömyys eivät suoraan sisälly edellisiin paradigmoihin, ehkä välillisesti dissipatiiviseen. Paradigmojen jatkopohdinnassa tämä ulottuvuus onkin syytä ottaa lähempään tarkasteluun.

Työyhteisö ei siis ole monoliittinen käsite, jota voitaisiin tutkia ja arvioida samoilla kriteereillä. Tähänastinen työyhteisöviestinnän tutkimus ja arviointi on perustunut pääosin rationaalisen koulukunnan ajatteluun, kun taas postmodernin työyhteisön ominaisuudet ovat jääneet katveeseen. Jatkossa olisi tarpeen operationalisoida viestinnän paradigmoja ja muodostaa arviointikriteerejä niiden pohjalta. Tästä hyötyisi sekä työelämän että viestinnän tutkimus.

\section{Kirjallisuus}

Adler, Paul \& Hekscher, Charles (2006) Towards Collaborative Community. Teoksessa Adler, Paul \& Hekcher, Charles (toim.) The Firm as a Collaborative Community. Oxford: Oxford University Press.

Alasoini, Tuomo (2006) Työnteon mielekkyyden muutos Suomessa vuosina 1992-2005. Raportteja 45. Helsinki: Tykes.

Antila, Juha (2006) Työn mielekkyydestä ja mielettömyydestä. Työpoliittisen tutkimusohjelman julkaisu 305. Helsinki: Työministeriö.

Antila, Juha \& Ylöstalo, Pekka (2002) Proaktiivinen toimintatapa. Työpoliittinen tutkimus 239. Helsinki: Työministeriö.

April, Kurt (1999) Leading through communication, conversation and dialogue. Leadership \& Organization Development Journal 20 (5), 231-241.

Aula, Pekka (1999) Organisaation kaaos vai kaaoksen organisaatio? Helsinki: Loki-Kirjat.

Barry, Norman (2002) The Stakeholder Concept of Corporate Control Is Illogical and Impractical. The Independent Review 6 (4), Spring 2002, 541-554.

Berger, Peter \& Luckmann, Thomas (1966) The Social Construction of Reality. Harmondsworth: Penguin Books.

Bordia, Prashant, Hobman, Elizabeth, Jones, Elizabeth, Gallois, Cindy \& Callan, Victor (2004) Uncertainty during organizational change: types, consequences, and management strategies, Journal of Business and Psychology, 18 (4), 507-532.

Byrne, Roger (2001) Employees: capital or commodity? The Learning Organisation, 8 (1), 44-50.

Carroll, Archie (1989) Business and Society. Ethics \& Stakeholder Management. Cincinnati: South-Western Publishing Co.

Carroll, Archie (1991) Pyramid of Corporate Social Responsibility: Toward the Moral Management of Organizational Stakeholders. Business Horizons, 34 (4), 39-48. 
Castells, Manuel (2000) The rise of the network society. Oxford: Blackwell.

Castells, Manuel \& Himanen, Pekka (2001) Suomen Tietoyhteiskuntamalli. Vantaa: WSOY.

Daniels, Tom, Spiker, Barry \& Papa, Michael (1997) Perspectives on Organizational

Communication. Boston: McGraw-Hill.

Elkington, John (1997) Cannibals with Forks: The Triple Bottom Line of 21st Century Business. London: Routledge.

Fiske, John (1982) Introduction to communication studies. Londonः Methuen.

Freeman, R. Edward (1984) Strategic Management: A Stakeholder Approach. Marchfield, MA: Pitman Publishing.

Freeman, R. Edward (1995) Stakeholder Thinking: The State of the Art. Teoksessa Näsi, J. (ed.) Understanding Stakeholder Thinking. Jyväskylä: LSR-Julkaisut and the Authors.

Goldhaber, Gerald, Dennis, H. \& Wiio, Osmo A. (1979) Information strategies. New Pathways to Management Productivity. New Jersey: Ablex Publishing Co.

Goris, Jose, Vaught, Bobby \& Pettit, John (2000) Effects of Communication Direction on Job performance and Satisfaction: a Moderated Regression Analysis. Journal of Business Communication, 37 (4), 348-368.

Green, Francis (2006) Demandin Work: The Paradox of Job Quality in the Affluent Economy. Princeton - Oxford: Princeton University Press.

Grunig, James \& Hunt, T. (1984) Managing Public Relations. New York: Holt, Rinehart \& Winston.

Grunig, James \& Grunig, Larissa (1992) Models of Public Relations and Communication. Teoksessa Grunig, James (toim.) Excellence in Public Relations and Communication Management. Hillsdale, N.J.: Lawrence Erlbaum Ass. Publishers.

Hatch, Mary J* (1997) Organisation Theory* Modern, Symbolic, and Postmodern Perspectives. New York: Oxford University Press.

Heinonen, Sirkka (2004) Tulevaisuuden työnteosta - vanhat paradoksit ja uusi paradigma. Helsinki: Toimihenkilöunioni.

Huotari, Maija-Leena, Hurme, Pertti \& Valkonen, Tarja (2005) Viestinnästä tietoon. Tiedon luominen työyhteisössä. Helsinki: WSOY.

Huhtala, Hannele (2004) The Emancipated Worker? A Faucauldian Study of Power, Subjectivity and Organising in the Information Age. Helsinkki: The Finnish Society of Science and Letters.

Joensuu, Sanna (2006) Kaksi kuvaa työntekijästä. Sisäisen viestinnän opit ja postmoderni näkökulma. Jyväskylä: Jyväskylä Studies in Humanities 58.

Juholin, Elisa (2004) Cosmopolis. Yhteiskuntavastuusta yrityskansalaisuuteen. Helsinki: Infor.

Juholin, Elisa (2007) Työyhteisöviestinnän uusi agenda. Työyhteisöviestintä 2010, raportti II. Helsinki: Haaga-Helia.

Juuti, Pauli \& Lindström, Kari (1995) Postmoderni ajattelu ja organisaation syvällinen muutos. Helsinki: Työterveyslaitos ja Johtamistaidon Opisto.

Kasvio, Antti (1995) Uusi työn yhteiskunta. Suomalaisen työelämän muutokset ja kehittämismahdollisuudet. Jyväskylä: Gaudeamus.

Keskinen, Soili (2005) Alaistaito. Luottamus, sitoutuminen ja sopimus, Helsinki: Kunnallisalan kehittämissäätiö.

Kinnunen, Ulla, Feldt, Taru ja Mauno, Saija (toim.) (2005) Työ leipälajina. Työhyvinvoinnin psykologiset perusteet. Jyväskylä: PS-kustannus.

Kuhn, Thomas (1962) The Structure of Scientific Revolutions. Chicago: The University of Chicago Press.

Lawrence, Paul \& Lorsch, Jay (1967) Organization and environment: managing differentiation and integration. Homewood (IL): Irwin.

Miller, Katherine (2003) Organizational Communication. Approaches and Processes. Wadsworth, Belmont.

Morgan, Gareth (1997) Images of Organisation. 2nd ed. Thousand Oaks, California: Sage Publications.

Morrison, Elisabeth \& Robinson, Sandra (1997) When employees feel betrayed: A model of how psychological contract violation develops. Academy of Management Review, 22 (1), $226-256$.

Näsi, Juha (1995) Understanding Stakeholder Thinking. Jyväskylä: LSR-Julkaisut and the Authors. 
Piirainen, Helena, Hirvonen, Maria, Elo, Anna-Liisa (2003) Työ- ja terveys haastattelututkimus. Helsinki: Työterveyslaitos.

Pyöriä, Pasi, Melin, Harri \& Blom, Raimo (2005) Knowledge Workers in the Information Society. Tampere: Tampere University Press.

Rantanen, Jorma (2004) Työ ja työntekijät. Teoksessa Kauppinen Timo, Hanhela Rauno, Heikkilä Pirjo, Lehtinen Suvi, Lindström Kari, Toikkanen Jouni, Tossavainen Antti, Työ ja terveys Suomessa 2003. Helsinki: Työterveyslaitos.

Rhenman, Eric (1964) Företagsdemokrati och företagsorganisation. Stockholm: Thule.

Siltala, Juha (2004) Työelämän huonontumisen lyhyt historia. Helsinki: Otava.

Simola, Ahti \& Kinnunen, Ulla (2005) Toimiva organisaatio henkilöstön hyvinvoinnin ja organisaation tuloksellisuuden kannalta. Teoksessa Kinnunen, Ulla, Feldt, Taru ja Mauno, Saija (toim.) (2005)

Työ leipälajina. Työhyvinvoinnin psykologiset perusteet. Jyväskylä: PS-kustannus.

Ståhle, Pirjo \& Grönroos, Mauri (1999) Knowledge Management - tietopääoma yrityksen kilpailutekijä. Helsinki: WSOY.

Taylor, Frederick (1911) The principles of scientific management. New York: Harper.

Tiainen, Pekka (2003) Työvoima 2020 loppuraportti. Osaamisen ja täystyöllisyyden Suomi. Työpoliittinen tutkimus 245. Helsinki: Työministeriö.

Torvi, Kari \& Kiljunen, Pentti (2005) Onnellisuuden vaikea yhtälö. Helsinki: EVA.

Tukiainen, Tuuli (2006) Työyhteisön ja toimintaympäristön kohtaamisia. Teoksessa Juholin, Elisa (toim.) Työyhteisöjen viestinnän uutta suuntaa etsimässä. Helsinki: Helia.

Työ ja terveys -haastattelututkimus (2006) Taulukkoraportti. Helsinki: Työterveyslaitos.

Venkula, Jaana (2005) Epävarmuudesta ja varmuudesta. Helsinki: Kirjapaja.

Virtanen, Akseli (2006) Biopoliittisen talouden kritiikki. Doctoral thesis. Helsinki School of Economics.

Von Bertalanffy, Ludwig (1968) General systems theory: Foundations, development, applications. New York: Braziller.

Weber, Max (1924/1947) The theory of social and economic organization. Glencoe, Ill.: Free Press.

Wiio, Osmo A. (1978/1995) Johdatus viestintään, 6. painos. Porvoo: WSOY.

Åberg, Leif (1989) Viestintä tuloksen tekijä. Helsinki: Tietopaketti Oy. 